\title{
Јанко Јуранчич \\ КАКО ЈЕ ВУКОВ СРПСКИ РЈЕЧНИК ОДЈЕКНУО У СЛОВЕНАЧКОЈ ЛЕКСИКОГРАФИЈИ
}

Француска револуција усталасала је духове и код Јужних Словена. Пароле о братству, једнакости и слободи одјекивале су међу нашом омладином у почетку XIX в. Избијали су проблеми о којима се дотле није чуло или су о њима говорили ретки појединци. Такви су проблеми били: националност, заједнички књижевни језик, књижевност и наука на народном језику, постављало се питање правописа, азбуке односно абецеде, расправљало се о речницима народног језика, говорило се о граматикама, које су се стварно и писале. Код угарских Срба све гласније се захтевало да се у књижевност уведе народни језик, Сава Мркаљ је размишљао о упрошћеној азбуци која би одговарала гласовној структури народног језика, Лука Милованов је предложио акценатске знакове помоћу којих би се могле што верније приказати фонолошке категорије и интонацијска структура народног језика. У Хрватској се озбиљно дискутовало и писало о томе како би се народни језик увео у сав јавни живот те да би се место дотадашњих покрајинских књижевних језика са кајкавском, чакавском и штокавском дијалекатском основом изградио јединствени књижевни језик за све хрватске покрајине. При крају XVIII в. ову је мисао најгласније израдио Јосип Шипуш. ${ }^{1}$ И у словеначким феудалним „круновинама”, у Крањској, Штајерској и Корушкој настаје живо превирање: 1808. објавио је Копитар „Grammatik der Slavischen Sprache in Krain, Kärnten und Steyermak”, 1825. Франц Метлеко издаје "Lehrgebäude der Slowenischen Sprache im Königreiche Illyrien und in den benachbarten Provinzen". Пет година пре Копитарове граматике групица источноштајерских родољуба већала је о издавању речника народног језика, затим је основана катедра словеначког језика прво на лицеју у

${ }^{1}$ Josip Šipuš, Temely xitne tergovine polag narave y dogacsajev, Zagreb 1796. 
Грацу и нешто касније на лицеју у Љубљани, 1817. У Штајерској објављене су и две граматике, „Theoretisch-praktische Windische Sprachlehere” „Lehrbuch der Windischen Sprache”, засноване на штајерском дијалекту. Најактивнији књижевни радник у Корушкој био је Урбан Јарник, који је превео поједине приче из Рајићевог „Цветника” те тако први успоставио књижевне везе са српским културним радницима. ${ }^{4}$ И, најзад, године 1804. букнуо је Први, а једанаест година касније Други српски устанак. У свима овим догађајима видимо политичку манифестацију грађанске Европе која се рађала из Велике револуције.

У средишту ових збивања, у борби за нову културно-националну физиономију код Јужних словена стоје три крупне личности: Јосеф Добровски, Јернеј Копитар и Вук Стефановић Караџић.

Године 1818. објављен је у Бечу „Српски рјечник”, истолкован њемачким и латинским ријечима. Скупио га и на свијет издао Вук Стефановић. Тако стоји записано на корицама Рјечника.

Идеју за овај посао Вуку је дао Копитар, који је пожртвовано сарађивао на изради речника, обавештавао Вука о многим језичким, правописним и другим лексикографским проблемима те преводио српске одреднице на немачки и латински језик. Копитар је Вуку посредовао најмодерније научне резултате из области немачке лингвистике, у првом реду из Аделунговог речника. ${ }^{5}$ Упозорио је Вука на старије „шокачке” лексикографе, на Микаљу, Дела Белу, Белостенца, Јамбрешића, Волтиџија и Стулија, те на дотада једини речник код Срба, на „Немецкиј и сербскиј словар" Теодора Аврамовића из 1790. године. Овим речницима Вук се служио за контролу свога језичког знања и у народу прикупљене лексичке грађе. У речнику је изоставио све речи које му нису биле познате из тршићког говора или које се нису налазиле у његовим записима. И ова критичност подсећа на Аделунга, који је свој речник назвао „Grammatisch-kritisches Wörterbuch”. И оваква опрезност према старијим речницима, који су били рађени на другој дијалекатској бази и у друкчијој идеолошко-друштвеној сфери, била је велика новост у нашој лексикографији, која је тешко себи крчила пут, као што показују многи словеначки, хрватски и српски речници из каснијег доба, нnр. Janežičev

2 Аутор Јанез Леополд Шмигоц, изашла у Грацу 1812.

3 Аутор Петер Дајнко, изашла у Грацу 1824.

${ }^{4}$ Zbér lépih ukov za slovensko mladíno. Iz Némškiga ino Latinskiga prestavlenih, iz Staro-Slavenskiga ino Pemskiga preravnanih, nikotérih pa novo zloženih, Celovec 1814.

5 Johann Christoph Adelung, Versuch eines vollständigen grammatischkritischen Wörterbuchs der hochdeutschen Mundart 1774/86. 
речник у 2. изд. Julija Kleimayra те у 3. и 4. изд. Franca Hubada. ${ }^{6}$ Тако се у Вуковом речнику здружило све за оно време највише и најбоље: ауторова природна даровитост, његова критичност те ванредно познавање народног језика, тековине старије хрватске лексикографије - којој иако је „старија” треба одати највише признање - и ерудиција словеначког научника, који посредује Вуку најмодернија учења о језику. С правом каже проф. П. Ивић: „Овај сусрет тековина хрватске лексикографије са почецима српске, уз подршку и старање једног великог Словенца, заслужује да нам данас буде посебно драг. Био је то један од првих контаката ових трију народа на пољу културе."

На оваквим модерним начелима састављен речник, који је, поред осталога, међународној лингвистици открио један живи словенски језик, дотада сакривен иза паравана славеносербскога књижевног језика, запажен је у ученој Европи, нарочито међу немачким и руским лингвистима, које је на речник упозорио Ј. Копитар. Релативно снажно одјекнуо је „Српски рјечник” и међу словеначким књижевницима, најпре сам речник, касније и Вукови погледи на књижевни језик. Међу претплатницима на речник налазимо имена тројице из Љубљане, а то су, како стоји записано: Г. Валентин Водник, свештеник и професор; барон Зигмунд Зоис од Едлштајн; Јаков Жупан, свештеник, доктор богословије и професор. Из Радгоне се претплатио на речник Петар Дајнко, каснији писац граматике. Четири претплатника из редова словеначких интелектуалаца за онај релативно мален број наших образовних људи и за низак ниво националне пробуђености свакако није мало. Сем тога, Љубљана је ипак далеко, за оно доба, од хрватске и српске језичке територије, где се углавном водила акција за сакупљање претплатника.

Вуков утицај у словеначкој књижевности и науци осећа се у два раздобља: прво, од објаве речника 1818. до мартовске револуције 1848 , нарочито у 20 -им и 30-им годинама, те друго, у 50-им годинама, код генерације која ступа на историјску позорницу после мартовске револуције. Прва фаза сва је испуњена интересовањима за језичка, правописна и абецедна питања, а у другој фази на првом је месту интерес за народну поезију, за превођење и објављивање народних песама из Вукових збирки, ${ }^{8}$ а у оригиналним делима иде трагом Вука Караџића најдоследнији словеначки вуковац Франце Левстик.

\footnotetext{
6 Антон Брезник, Iz zgodovine novejših slovenskih slovarjev, CZN XXXIII, 158-164.

Српски рјечник, јубиларно издање 1964, Поговор, 38.

8 Главни су преводиоци: Франце Цегнар, Лука Светец, Карел Дежман.
} 
Левстик је познавао Вукова дела, без сумње, већ као ђак љубљанске гимназије, а Вукова начела о књижевном језику и о садржају књижевних дела почео је примењивати у својим списима после личног састанка са српским реформатором у Бечу у пролеће 1855 . На састанку је било говора и о актуелним проблемима словеначке књижевности. Левстику је било јасно да је хиљадугодишња политичка зависност словеначких земаља задала дубоке ране и народном језику. А још горе стајало је са књижевним језиком. Писци 50-их година, неки и мање даровити и без Левстикове борбености и јасности у програму, мислили су, како их оптужује Левстик, немачки и своје мисли ропски преносили у тобожњи словеначки језик, који је био публици, нарочито сељачкој, неразумљив. Преводиле су се, по Левстиковим речима, немачке фразе, копирала се структура немачког језика. „Сви који пишемо” - наставља Левстик - „служимо се словеначким речима, али мислимо немачки... Томе се не треба чудити. Наши образовани људи остављају свој завичај као деца, одлазећи у школе, а затим живе у градовима, говоре већим делом немачки, читају највише немачке књиге, поред књижевних дела других народа....” Ова Левстикова критика стања у словеначкој књижевности заправо је паралела Вуковој критици књижевних прилика код Срба у почетку XIX века: „Ако се наш списатељ родио у вароши, он већ није ни чуо правога и чистога Српског језика; ако ли се родио у селу, он је у детињству дошао у варош, и онђе за 10-15 година учећи науке на туђим језицима, мора заборавити и мислити Српски..." ${ }^{10}$

У овој мрачној, очајној ситуацији Левстик је, као некада Вук, указао на изворе правога и чистог народног језика, на сељачки елеменат. „Извор словеначком језику - каже Левстик - још увек је сељак и народ изван градова." ${ }^{11}$ А на другом месту истиче: „Хоћеш ли бити писац, прво треба да савладаш језик колико је год могуће, а затим добро да упознаш свој народ - јер иначе ти је празно све што год брбљаш онако у ветар!"12

Али не само језик свога народа, словеначки писац мора - тако је мислио Левстик - учити и научити и Вуков језик: „Сваки словеначки писац морао би од свих наречја” - то јест словенских језика - „у првом реду да зна српски или у најмању руку барем српски." ${ }^{13}$

У једној својој критици Левстик истиче да није само немачки културни и језички утицај онај чинилац који је уздрмао основицу слове-

9 Fr Levstik, Napake slovenskega pisanja, Zbr. delo V, 1933, 101.

10 Српски рјечник, Предговор, V.

11 Levstik, o. c. 101.

12 Levstik, Popotovanje od Litije do Čateža, Zbr. delo III, 1931, 51/52.

13 Levstik, o. c. 15. 
начке националне индивидуалности. Огромну штету наноси књижевном језику и несистематско узимање речи и других језичких елемената из различитих словенских језика: „Недавно је наша књижевност запала у ћорсокак. Писало се понекад мало руски, па опет мало илирски или чешки. Неки су свом бљутавом јелу додавали још покоји старословенски чварак да би тако то јело мирисало на старину. Најчешће су наши писци писали како је коме на врх пера дошло. Нико се није питао ни за каква правила. Такав је начин писања, наравно, врло угодна ствар, јер ту ништа не треба да учиш!”14 То је словеначка „баба Смиљана”. Сличним речима прекорава Вук у Предговору Српског рјечника лоше писце: „Никаквим језиком на овом свијету није тако ласно писати, као овим њиовим: код њи не треба знати никакве граматике (ни Српске ни Славенске), него зарежи перо па пиши по своме вкусу, како ти кад из пера истече: што не знаш Српски, метни Славенски; што не знаш Славенски, метни Српски; а што не знаш ни Српски ни Славенски, метни како ти драго (што ти прије на ум падне)...”15

И не само у питању књижевног језика, Левстик се угледао на Вука и у методу књижевног рада и у самом књижевном програму. У „Popotovanju od Litije do Čateža” каже: „Песме српског народа треба да нас поуче како се описује!" ${ }^{16}$ Словеначким писцима препоручује да читају српске народне епске песме, да их проучавају, а српски десетерац назива словенским јуначким метром. ${ }^{17}$ Студиозно пише чланак о метрици српских народних песама, ${ }^{18}$ естетске одлике епских народних песама наводи као примере савршеног уметничког описивања, ${ }^{19}$ у лик Мартина Крпана уноси, како сам каже у првој редакцији приповетке, и неке црте Тешана Подруговића. Па и саму идеју да се књижевност постави на фолклорну основу, Левстик је могао наћи у Вуковим списима.

Од лексикографских дела овде ћу се осврнути на четири основна речника наше лексикографије XIX века, од којих сваки представља нешто своје, у позитивном или у негативном значењу речи. Сваки од њих је у одређеном односу према Српском рјечнику, али сваки у различитом.

${ }^{14}$ Levstik, Gospodoma nasprotnikoma, Zbr. delo V, 1933, 168/9.

${ }^{15}$ Српски рјечник, Предговор VI.

16 Zbrano delo, III, 1931, 55.

${ }_{17}$ Pegam in Lambergar, Zbrano delo V, 1933, 61.

${ }^{18}$ O metriki srbskih narodnih pesmi, Zbrano delo V, 321-26.

${ }_{19}$ Kritika o Koseskem, Zbrano delo V, на различитим местима. 
То су речници које су саставили Антон Мурко, ${ }^{20}$ Антон Јанежић, ${ }^{21}$ Матеј Цигале ${ }^{22}$ и Макс Плетершник. ${ }^{23}$

Речник Антона Мурка је изашао пре но што је Гајев илиризам пљуснуо преко хрватских граница у периферне словеначке области. Зато су аутору речника потпуно туђа каснија илирска настојања да се за све Јужне Словене, за Хрвате, Србе и Словенце изгради заједнички књижевни језик. Према томе, Мурко би могао остати у границама словеначког језика, који до тада још није био у стању да изгради свој јединствени књижевни језик. Мурко је желео да да̂ речник који би здружио све словеначке покрајине у једном заједничком књижевном језику. О овој његовој жељи говори и примедба на насловној страни речника: „Kakor se slovénščina govorí na Štájerskim, Koròškim, Korájnskim in v’ zahodnih stranih na Vógerskim". Али, према жељи издавача, аутор је морао саставити опширан речник. Зато је у своје дело унео сав материјал који је нашао у домаћој књижевности, укључивши при томе и источне писце, који су са својим дијалекатским лексичким фондом готово непознати крањској читалачкој публици. За лексичким материјалом трагао је и по туђим речницима, често без икакве потребе, јер је адекватну реч, много бољу, могао наћи у живом народном језику. У свој речник унео је речи из Добровскога Institutiones, из Deutsch-böhmisches Wörterbuch, 1802/21, из Slavina I, из Heymovog речника руског језика, а највећи број из Белостенца и Српског рјечника. ${ }^{24}$ А. Брезник наводи у својој студији преко 20 речи које су несумњиво узете из Вуковог речника.

Међутим, у 30-им и 40-им годинама XIX в. збивају се важни догађаји у политичком и културном животу Јужних Словена. Да споменемо само два од њих: 1836. уводи Гај крупне промене у питању књижевног језика код Хрвата с тим да је укинуо кајкавско наречје као локално књижевно наречје и место њега узео штокавски дијалект, којему намењује улогу заједничкога књижевног језика за све Јужне Словене. Четрнаест година касније састали су се у Бечу представници Срба и Хрвата, састанку је присуствовао и Миклошић, да би се договорили о заједничком и јединственом књижевном језику. Тако су се ту нашли представници трију нација које су касније себи избориле трајну симбиозу у слободи. У

${ }^{20}$ Slovénsko-Némški in Némško-Slovénski róčni besédnik. V. Gradci 1833.

${ }^{21}$ Popolni ročni slovar slovenskega in nemškega jezika, Nemško-slovénski del; Slovénsko-nemški del, Celovec 1851.

${ }^{22}$ Deutch-slovenisches Wörterbuch. Erster Theil A - L, Zweiter Theil M - Z, Laibach 1860 .

${ }^{23}$ Slovensko-nemški slovar. Prvi del A - O, 1849; Drugi del P - Z. V Ljubljani 1895.

${ }^{24}$ A. Breznik, Iz zgodovine novejših slov. slovarjev, ČZN XXXIII, 24. 
атмосфери Гајева илиризма и Бечког договора наступа једна од најмаркантнијих црта словеначке лексикографије и рада на формирању књижевног језика уопште, наиме тежње да се словеначки књижевни језик што више приближи словенским књижевним језицима, у првом реду, наравно, српскохрватском, који у ово доба фунгира још као Вуков с једне и као „илирски” с друге стране. Приближавање се врши у првом реду у лексици, а до неке мере и у синтакси, морфологији и фонетици. Крањски дијалекатски облици: братом, добрига, добриму, ловаи, нарвечји замењени су штајерским облицима братом, добрега, добрему, ловеи, највечји, који су у много чему приближили словеначки књижевни језик осталим словенским језицима. Лексичка изједначивања с осталим Словенима тражио је и један део публике. Када се већ спремао Јанежићев речник, један дописник из Горице тражио је у новинама Словенија од 22. јуна 1849. да нови речник „ро da roko Jugoslavjanom.... Дописник соколи писца речника да се уз словеначке одреднице не боји додавати и хрватских и српских речи. „Tako se bomo Jugoslavjanom bližali”. ${ }^{25}$

Јанежић је жељи овога дописника у пуној мери удовољио. Словеначко-немачки и Немачко-словеначки речник имао је у I изд. масу српскохрватских речи, али ни за коју се не може рећи да је узета из Српског рјечника, него се састављач при томе служио мање квалитетним „Илирско-немачко-талијанским малим речником Јосипа Дробнича и Антуна Мажуранића" (1846-49).

Највећи и најозбиљнији подухват словеначке лексикографије у XIX в. представља двотомни Немачко-словеначки речник, који је, уз сарадњу већег броја скупљача лексичког материјала те уз помоћ стручњака-лингвиста, саставио Матија Цигале. Тридесетак година касније изашао је такођер двотомни Словеначко-немачки речник, који је редиговао М. Плетершник. И на овом речнику сарађивао је приличан број скупљача лексичке грађе. И за први и за други речник материјал се прикупљао у народу и у литератури од почетка столећа.

Цигале је први словеначки лексикограф који је лексикографију поставио на научну базу. Био је одличан зналац језика и лингвистички образован. Он наводи источнике и цитира књиге из којих узима грађу, критички претреса лексику словеначког књижевног језика, у коју су ранији лексикографи, многи без лингвистичког образовања и довољно критичности, унели мртав материјал из различитих речника, највише хрватских, из Белостенца, Јамбрешића, Стулија и Дела Беле.

${ }^{25}$ Ibid. 95. 
Добар познавалац словеначког језика био је и Плетершник, солидно лингвистички образован, по природи тачан, савестан и вредан. Цигале и Плетершник располагали су релативно богатом грађом - Плетершников речник има 110.000 одредница - па су стога у мањој мери били принуђени да пабирче по различитим словенским речницима и некритички уносе често и сумњиве речи у своје дело. Али хрватским и српским речницима, у конкретном случају Вуковим, служили су се и они, само друкчије од Мурка или Јанежића. Цигале се ослонио на Шулеков речник, али само до слова Н, јер је тамо Цигале Шулека престигао, а из Вука наводи, врло често, његове изразе као еквиваленте уз словеначки превод немачке одреднице, нпр. bösartig hudoben, zloben... серб. злоћудан; - deutlich разлочин, разумљив... серб. разговетан; - или начини реч угледајући се на „српски” пример: der Bote послани, посланец... nach dem Serb. гласник итд. Да Serbisch значи исто што Вуков речник, каже Цигале сам на непагинираној страни испред речника: Unter serbisch wird in diesem Wörterbuche jene Sprache verstanden, welche in Vuk's Рјечник verzeichnet ist. Плетершник узима речи из хрватских и српских речника и то све означава као $x c$ (= хрватски и српски), а из Вука свакако мало или можда чак и ништа. Плетершник има хс речи којих нема ни у 3. изд. Вуковог речника, нпр. бродарити, што је могао узети из Рјечника ЈАЗУ. Иначе често позајмљује речи из Хабделићева Дикционара, што је свугде забележио (Хабд.). Узимање из Хабделићевог речника није, како је Плетершник ствар разумео, позајмљивање из хрватског речника, јер је тада, према Копитаровој и Миклошићевој класификацији дијалеката, кајкавско наречје сматрано за оригинални део словеначког језика. И још у једној ствари Цигале и Плетершник поводе се за Вуком, наиме у жељи да даду у својим речницима што вернију и што поузданију слику народног и књижевног језика, да уклоне из речника све мртве наносе из прошлости, да не пабирче по туђим речницима када за ово не постоји никаква потреба, да цитирају источнике и помало уводе квалификаторе.

Борба против туђих речи у књижевном језику у посленаполеонско доба разбуктала се нарочито код Немаца. Филозоф Fichte, лексикограф Joachim Heinrich Campe и њихови савременици заузели су оштар став према француским туђицама, које су се у току XVIII в. наметнуле немачком књижевном језику. У француским туђицама видели су и политичку опасност $^{26}$. Слично се према туђицама односио и Вук Караџић, којега је Копитар могао тачно да обавести о стању у немачкој књижевности. Вук је турске речи, које су по његовом мишљењу органски део народне лекси-

${ }^{26}$ A. Bach, Geschichte d. deutschen Sprache, 9. изд., 334. 
ке, унео у свој речник, али их је означио звездицом. Међутим, искључена је била свака реч „из војвођанских крајева која би била славеносербског, немачког или мађарског порекла (тако је у једном тренутку наше културне историје дошло до парадоксалне ситуације: прогањани су термини за одређене појмове културе и цивилизације најнапредније српске средине, док међутим, турске позајмице - типа чаршија, пенџер и сл. - затечене претежно у заосталијим крајевима нису прогањане". ${ }^{27}$

Овакав Вуков поступак и различит однос према турским и немачким туђицама оправдава се тиме што су многи турцизми, у оно доба и на ужем језичком подручју, у самој Србији, заиста били незамењиви, на пример чарапа, марама, јорган итд. - као што је исти случај, свакако, био са неким германизмима код јужноугарских Срба - али Вук је тачно оценио који од обадва језика, турски или немачки, представља већу опасност по српски језик. Аустрија са својом немачком управом, немачким језиком у војсци, у школама и надлештвима непосредно је угрожавала опстанак српства, док се културно мање развијена Турска у ово време већ помало распадала. Српски устанци били су једна од етапа у политичкој распродаји турске државе.

У сличном односу према туђим речима налазио се тада и словеначки језик. Немачки, као државни језик у Монархији, од јозефинизма све агресивнији, у XIX в. брзо помера нашу језичку границу према југу, градови на словеначкој територији добијају све више германски изглед. Све то изазива отпор код словеначких патриота. Трубару германизми у језику још нису много сметали, али у XIX в. чистило се из језика све чему се могло доказати туђе, у првом реду немачко порекло. Према романским туђицама словеначки пуристи били су равнодушнији, јер Романи нису представљали неку нарочиту опасност.

Најзад, споменућу још да су граматичари Дајнко и Метелко стварали своју абецеду угледајући се на Вукову азбуку. Дајнко је узео знак за глас $и$ и према ћирилском ғь начинио свој знак $n$ ј. Још више узео је од Вука Метелко. Слова за з, и и ч неизмењена просто је пренео из вуковице, слова за $l j$ и $n j$ је начинио према ћирилским словима.

Да поставимо још једно питање! Каква је судбина чекала Јужне Словене, Србе, Хрвате и Словенце, да Вука није било, да се није срео с Копитаром или да Вукова борба није успела?

Копитар је у мају 1819. писао министру полиције Sedlnitzkom у Бечу: „Илирски народ, како римског тако и грчког обреда, говори потпуно јед-

${ }^{27}$ М. Ивић, Вукова улога у нормирању екавске варијанте књижевног језика, Анали Филол. фак. II, 96/97. 
нако. Али свештенство овог последњег обреда настоји да уклони једнакост говора на тај начин што језик општења који је код католика већ три стотине година књижевни језик проглашава жаргоном којим се не може писати и зато покушава да натури своме стаду мртви старословенски језик из руских црквених књига за књижевни језик"28. Копитарова католичка горљивост, његов аустријски патриотизам те његова мржња према руском православљу, све то је преко Вука и његова рада онемогућило да би се код Срба афирмисала русификована варијанта старословенскога као књижевног језика. То што се српски књижевни језик није удаљио од народног омогућило је Људевиту Гају да за јединствени хрватски језик изабере штокавско наречје, блиско Вуковој штокавској варијанти, и које је онда докинуло различите књижевне језике на кајкавској, чакавској и штокавској дијалекатској бази код политички и културно разједињених Хрвата. Без претходног духовног уједињења и зближења у књижевном језику између Хрвата и Срба у XIX в. била би осујећена било каква каснија политичка акција у циљу ослобођења. Да се наша национална проблематика тада није решила у смислу Вукове и Гајеве концепције, судбина словеначког народа била би сасвим другачија, много тежа, можда катастрофална.

То признање наш је прилог прослави Вукових дана.

\section{ЛИТЕРАТУРА}

Вук Стеф. Караџић, Српски рјечник (1818). Сабрана дела Вука Караџића, књ. II, прир. Павле Ивић, Просвета, Београд 1964.

A. J. Murko, Slovénsko-Némški in Némško-Slovénski róční besédnik, V’ Gradci 1833. M. Cigale, Deutsch-slovenisches Wörterbuch, Erster Theil A - L, Zweiter Theil M - Z, Laibach 1860.

M. Pleteršnik, Slovensko-nemški slovar, I, A - O, 1894, II, P - Z. Lj. 1895.

J. Kopitar, Grammatik der Slavischen Sprache in Krain, Kärnten und Steyermark, Laibach 1808.

J. L. Šmigoc, Theoretisch-practische Sprachlehre, Grätz 1824.

P. Dajnko, Lehrbuch der Windischen Sprache, Grätz 1824.

F. Matelko, Lehrgebäude der Slowenischen Spreche im Königreiche Illyrien und in den benachbarten Provinzen, Laibach 1825.

A. J. Murko, Theoretisch-praktische Slowenische Sprachlehre, Grätz 1832.

${ }^{28}$ Миодраг Павловић, Вук Стеф. Караџић, Београд, 1964, 104/5. 
П. П. Ђорђевић, Скупљени граматички и полемички списи Вука Стеф. Караџића I-III, Београд 1894-96.

Љ. Стојановић, Живот и рад Вука Стеф. Караџића, Београд 1924.

Миодраг Поповић, Вук Стеф. Караџић, Београд 1964.

А. Белић, Вукова борба за народни и књижевни језик, Београд 1948.

А. Белић, Вук и Даничић, Београд, 1947.

Д. Брозовић, Српскохрватски стандардни језик и Вук Стефановић Караџић, Анали Филол. фак. II, Београд 1965, 27-34.

М. Ивић, Вукова улога у нормирању екавске варијанте књижевног језика, Анали Филол. фак. II, Београд 1965, 95-98.

П. Ивић, Два аспекта Вуковог дела, Анали Филол. фак. II, Београд 1965, 99-107. J. Јуранчић, Вук и Словенци, Анали Филол. фак. I, Београд, 1964, 197-200.

A. Slodnjak, Vuk in slovensko slovstvo, Vukov zbornik, Beograd 1966, 207-228.

A. Breznik, Iz zgodovine novejših slovenskih slovarjev, ČZN XXXIII.

F. Kidrič, Peter Dajnko, SBL 1. zv., 111 и д.

I. Grafenauer, Anaton Janežič, SBL 3. zv., 376 и д.

Е. Kernc, Jernej Kopitar, SBL 4. zv., 496 и д.

J. Glonar, Anton Murko, SBL 6. zv., 166 и д.

A. Breznik, Maks Pleteršnik, SBL 7 zv., 381 и д.

S. Suhadolnik, Cigaletov besednjak, JiS 1959/60, 225-30. 